\title{
Hubungan Higienitas Vagina, Kadar Gula Darah dan Kadar Hormon Estrogen dengan Kejadian Kandidiasis Vaginalis
}

\author{
Silfina Indriani ${ }^{1}$, Netti Suharti ${ }^{2}$, Almurdi $^{3}$ \\ Ilmu Kebidanan, Fakultas Kedokteran, Universitas Andalas, Padang ${ }^{1}$ \\ Kesehatan Masyarakat, Fakultas Kedokteran, Universitas Andalas, Padang ${ }^{2,3}$ \\ Email: silfinaindriani@gmail.com
}

\begin{abstract}
Candida albicans is a normal flora in several areas of the human body and has opportunistic properties, so that if conditions support, it will be able to transform into pathogens (Ramali and Werdani, 2001). Candida can become pathogenic if there are predisposing factors, one of which is diabetes mellitus (DM), the frequency of underwear replacement (Anindita, 2006) and the use of contraceptives that affect the balance of estrogen hormones (Amelia, 2009). Researchers are interested in discussing the relationship of vaginal hygiene, blood sugar levels and estrogen hormone levels with vaginalis candidiasis. The purpose of this research was to determine the relationship of vaginal hygiene, blood sugar levels and estrogen hormone levels with vaginalis candidiasis. This research is a quantitative research with a type of analytical research studies. The research design used was a cross sectional comparative study. It was carried out at the Bhayangkara Hospital Polyclinic and Padang Pasir Health Center as well as Nanggalo. The population in this research were all women of fertile age who came to the obstetric polyclinic who conducted Visual Acetate Acid (IVA) Inspection. The sample in this research is the population that meets the inclusion and exclusion criteria. The hypothesis of this research is the relationship between vaginal hygiene, blood sugar levels and estrogen hormone with vaginalis candidiasis. There is a relationship between vaginal hygiene, blood sugar levels and estrogen hormone with vaginalis candidiasis. The conclusion of this research is that the dominant factor with vaginalis candidiasis is vaginal hygiene with an OR value of 11.37 .
\end{abstract}

Keywords: Vaginal Hygiene, Blood Sugar, Estrogen Hormone, Vaginalis Candidiasis.

\section{PENDAHULUAN}

Candida albicans merupakan flora normal pada beberapa area tubuh manusia serta memiliki sifat oportunis sehingga apabila kondisi mendukung, akan dapat berubah menjadi patogen (Ramali dan Werdani, 2001). Candida dapat menjadi patogen jika terdapat faktor predisposisi, salah satu di antaranya adalah diabetes melitus (DM). Pasien DM berisiko lebih tinggi terhadap terjadinya kandidiasis vaginalis. Hal ini disebabkan karena tingginya kadar glukosa darah menyebabkan meningginya kadar glukosa kulit pada pasien DM sehingga mempermudah timbulnya manifestasi kulit berupa dermatitis, infeksi bakterial, infeksi jamur, dan lain-lain (Djuanda, 2008). Hal ini didukung oleh penelitian sebelumnya menyebutkan bahwa terjadi abnormalitas sistem imun pada penderita DM sehingga berakibat meningkatnya kejadian infeksi kulit (Menezes, 2007). Kondisi sel epitel dan mukosa pada penderita DM juga mengalami peningkatan adhesi terhadap beberapa mikroorganisme patogen seperti Candida albicans di mulut dan sel mukosa vagina (Stoeckle, 2008). Kadar gula yang meningkat pada darah dan urine akan mempermudah infeksi Candida albicans yang memanfaatkan gula sebagai nutrisi untuk pertumbuhannya (Marschalek, 2016).

Kebersihan vagina dan kelembaban pada vagina yang tidak terjaga dapat menyebabkan banyak keringat terutama pada lipatan-lipatan kulit seperti daerah kemaluan sehingga menyebabkan kulit maserasi. Kondisi ini mempermudah invasi dan kolonisasi Candida albicans (Siregar, 2005; Siregar, 2012).

Hasil penelitian Anindita (2006) diketahui terdapat hubungan antara frekuensi penggantian pakaian dalam (higienitas vagina) dengan kejadian kandidiasis vaginalis yang bermakna secara statistik. Risiko terkena kandidiasis vaginalis pada responden yang dengan frekuensi penggantian pakaian dalam 2,39 lebih besar dibanding yang tidak menganti dengan baik. Gama (2006) menunjukkan bahwa responden yang memiliki perilaku higiene seksual yang buruk mempunyai besar risiko 7 kali terkena kandidiasis dibandingkan perilaku higiene seksual yang baik. 
Penelitian yang dilakukan Wahyuni (2007) menyatakan persentase kejadian diabetes mellitus pada wanita usia subur pada usia reproduksi (15-49 tahun) adalah 3,6\%. Penelitian Amelia (2009) diketahui terdapat hubungan yang bermakna antara kadar gula darah dengan kejadian kandidiasis vagina ( $p$ value < 0,05). Penelitian Anindita (2006) menyatakan bahwa variabel yang berpengaruh terhadap kejadian kandidiasis vaginalis adalah pemakaian alat kontrasepsi AKDR/Pil yang mempengaruhi ketidakseimbangan hormon estrogen dengan $p=0,005$ ( $p$ value $<0,05$ ). Hasil penelitian Afrianty (2016) diketahui terdapat perbedaan kadar hormon estrogen dengan kandidiasis vaginalis.

Berdasarkan latar belakang diatas, maka peneliti tertarik untuk membahas lebih dalam mengenai hubungan higienitas vagina, kadar gula darah dan kadar hormon estrogen dengan kejadian kandidiasis vaginalis.

Rumusan masalah dalam penelitian ini adalah bagaimana hubungan higienitas vagina, kadar gula darah dan kadar hormon estrogen dengan kejadian kandidiasis vaginalis. Tujuan dari penelitian ini adalah untuk mengetahui hubungan higienitas vagina, kadar gula darah dan kadar hormon estrogen dengan kejadian kandidiasis vaginalis.

Manfaat penelitian ini adalah diharapkan dapat meningkatkan pelayanan oleh petugas kesehatan sehingga dapat memotivasi masyarakat khususnya wanita usia subur agar dapat sering mememeriksakan kesehatan untuk mencegah dan mengobati keputihan dan kejadian kandidiasis vaginalis serta memberikan penyuluhan tenteng higienitas vagina sehingga dapat menghindari terjadinya infeksi, menambah khasanah keilmuan tentang faktor risiko kejadian kandidiasis vaginalis, diharapkan penelitian ini dapat mendorong penilitian selanjutnya tentang kejadian kandidiasis vaginalis pada wanita usia subur.

Tujuan dari penelitian ini adalah untuk mengetahui hubungan higienitas vagina, kadar gula darah dan kadar hormon estrogen dengan kejadian kandidiasis vaginalis.

\section{METODE PENELITIAN}

Penelitian ini merupakan penelitian kuantitatif dengan jenis penelitian studi analitik. Desain penelitian yang digunakan adalah cross sectional comparative study. Penelitian ini telah dilakukan di Poliklinik RS Bhayangkara, Puskesmas Padang Pasir dan Puskesmas Nanggalo. Sampel darah akan di sentrifuge di Laboratorium Rumah Sakit dan Puskesmas tempat penelitian, pemeriksaan kadar serum estrogen dilakukan di Balai Laboratorium Kesehatan Padang dan pemeriksaan mikroskopis candidiasis vaginalis dilakukan di Laboratorium Mikrobiologi Fakultas Kedokteran Univarsitas Andalas Padang. Penelitian ini telah dilakukan mulai Februari - Maret 2018.

Populasi pada penelitian ini adalah semua wanita usia subur yang datang ke poliklinik obstetri RS Bhayangkara, Puskesmas Padang Pasir dan Puskesmas Nanggalo yang melakukan pemeriksaan Inspeksi Visual Asam Asetat (IVA). Sampel pada penelitian ini adalah bagian dari populasi yang memenuhi kriteria inklusi dan eksklusi penelitian.

Analisis univariat yang dilakukan untuk menghitung distribusi frekuensi higienis vagina dan kadar gula darah. Nilai rerata dan standar deviasi untuk kadar hormon estrogen. Sebaran data dinilai dengan uji normalitas Shapiro wilk (n < 50). Analisa bivariat digunakan uji chi square. Perbedaan kadar hormon estrogen dengan kejadian kandidiasis vaginalis menggunakan uji statistik independent $t$ test pada data yang berdistribusi normal sedangkan pada data yang berdistribusi tidak normal digunakan uji mann whitney. Analisis multivariat menggunakan uji regresi logistik ganda dengan metode enter.

\section{HASIL DAN PEMBAHASAN Normalitas Data}

Tabel 1. Uji Normalitas Data

\begin{tabular}{clccc}
\hline Variabel & \multicolumn{1}{c}{ Kelompok } & N & Mean \pm SD & p value \\
\hline Kadar Estrogen $(\mathrm{pg} / \mathrm{ml})$ & Kandidiasis Vaginalis & 29 & $143,39 \pm 151,16$ & 0,000 \\
& Tidak Kandidiasis Vaginalis & 29 & $60,99 \pm 52,39$ & 0,001 \\
\hline
\end{tabular}

Berdasarkan tabel 1 diketahui bahwa hasil uji normalitas kadar estrogen pada kelompok kasus dan kontrol tidak terdistribusi normal dengan $\mathrm{p}<0,05$. Peneliti melakukan transformasi data karena pada variabel kadar estrogen kelompok kandidiasis vaginalis dan tidak kandidiasis vaginalis tidak terdistribusi normal. Transformasi dilakukan peneliti dengan 
menggunakan fungsi $\log 10$, dengan hasil transformasi dapat dilihat pada tabel 2.

Tabel 2. Uji Normalitas Data Setelah Transformasi Data

\begin{tabular}{clccc}
\hline Variabel & \multicolumn{1}{c}{ Kelompok } & n & Mean \pm SD & p value \\
\hline Kadar Estrogen $(\mathrm{pg} / \mathrm{ml})$ & Kandidiasis Vaginalis & 29 & $1,87 \pm 0,59$ & 0,053 \\
& Tidak Kandidiasis Vaginalis & 29 & $1,62 \pm 0,42$ & 0,383 \\
\hline
\end{tabular}

Dari tabel 2 diketahui bahwa hasil uji normalitas kadar estrogen pada kelompok kandidiasis vaginalis dan tidak kandidiasis vaginalis terdistribusi normal dengan $\mathrm{p}>0,05$.

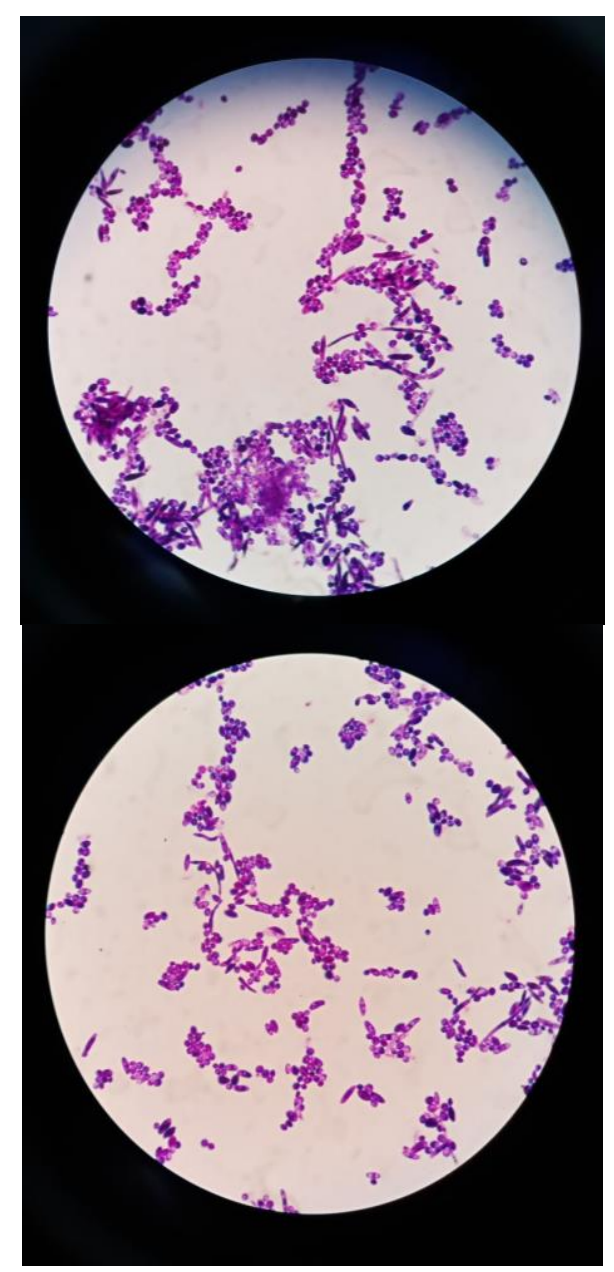

\section{Kandidiasis Vaginalis}

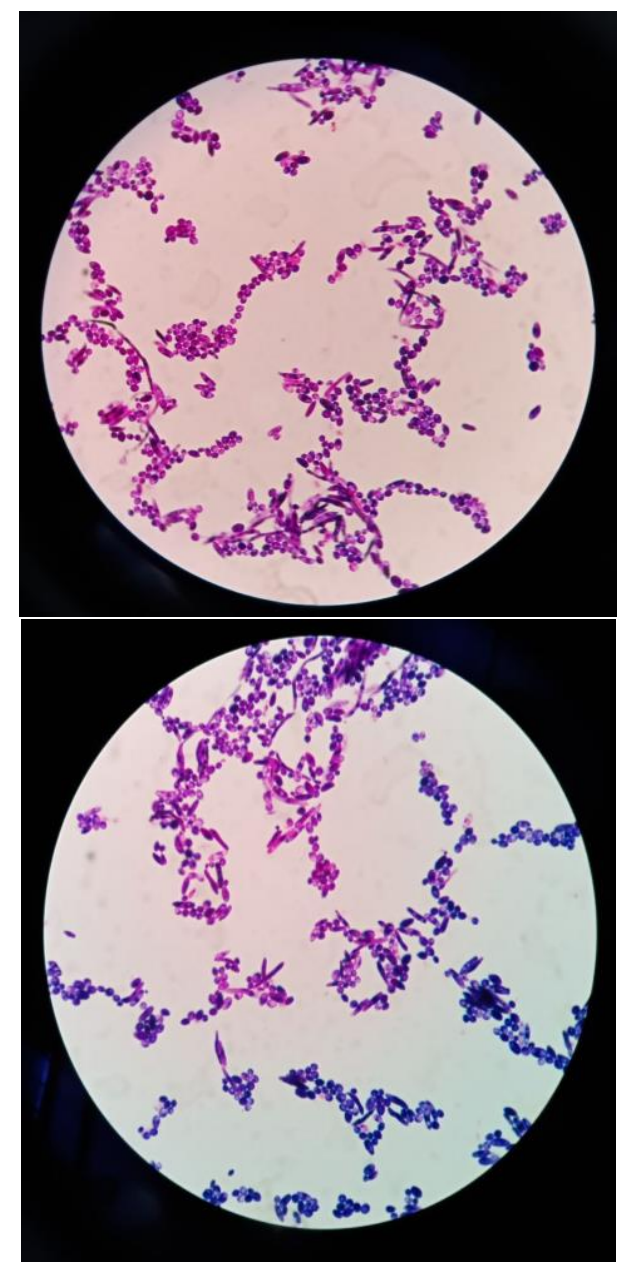

Gambar 1 Pseudohifa pada Pewarnaan KOH dalam Mengidentifikasi Candida albicans

Berdasarkan gambar 1 diketahui Candida sp. membentuk koloni lunak berwarna krem dan beragi. Candida albicans bersifat dimorfik, menghasilan ragi dan pseudohifa. Pseudohifa pada gambar 5.1 tampak setelah dilakukan pewarnaan gram. .

Hubungan Antara Higienitas Vagina dengan Kejadian Kandidiasis Vaginalis 
Tabel 3. Hubungan Antara Higienitas Vagina dengan Kejadian Kandidiasis Vaginalis

\begin{tabular}{lccccccc}
\hline \multicolumn{1}{c}{$\begin{array}{c}\text { Higienitas } \\
\text { Vagina }\end{array}$} & $\begin{array}{c}\text { Kandidiasis } \\
\text { Vaginalis }\end{array}$ & $\begin{array}{c}\text { Kelompok } \\
\text { Tidak Kandidiasis }\end{array}$ & \multicolumn{2}{c}{ Jumlah } & p value \\
& f & \% & f & \% & f & \% & \\
\hline Tidak Baik & 24 & 82,8 & 9 & 31 & 33 & 56,9 & \\
Baik & 5 & 17,2 & 20 & 69 & 25 & 43,1 & 0,000 \\
Jumlah & 29 & 100 & 29 & 100 & 58 & 100 & \\
\hline
\end{tabular}

Tabel 3 menunjukkan bahwa pada kelompok kandidiasis vaginalis persentase responden dengan higienitas tidak baik yaitu $82,8 \%$ lebih tinggi dibandingkan tidak menderita kandidiasis vaginalis yaitu $31 \%$. Hasil uji statistik didapatkan nilai $\mathrm{p}=0,000$ ( $\mathrm{p}$ value <
0,05) maka dapat disimpulkan terdapat hubungan antara higienitas vagina dengan kejadian kandidiasis vaginalis.

Hubungan Antara Kadar Gula Darah dengan Kejadian Kandidiasis Vaginalis

Tabel 4. Hubungan Antara Kadar Gula Darah dengan Kejadian Kandidiasis Vaginalis

\begin{tabular}{|c|c|c|c|c|c|c|c|}
\hline \multirow{3}{*}{$\begin{array}{c}\text { Kadar Gula } \\
\text { Darah }\end{array}$} & \multicolumn{4}{|c|}{ Kelompok } & \multirow{2}{*}{\multicolumn{2}{|c|}{ Jumlah }} & \multirow{3}{*}{ p value } \\
\hline & \multicolumn{2}{|c|}{$\begin{array}{l}\text { Kandidiasis } \\
\text { Vaginalis }\end{array}$} & \multicolumn{2}{|c|}{$\begin{array}{c}\text { Tidak Kandidiasis } \\
\text { Vaginalis }\end{array}$} & & & \\
\hline & $\mathbf{f}$ & $\%$ & f & $\%$ & f & $\%$ & \\
\hline $\mathrm{DM}$ & 15 & 51,7 & 2 & 6,9 & 17 & 29,3 & \\
\hline Tidak DM & 14 & 48,3 & 27 & 93,1 & 41 & 70,7 & 0,001 \\
\hline Jumlah & 29 & 100 & 29 & 100 & 58 & 100 & \\
\hline
\end{tabular}

Tabel 4 menunjukkan bahwa pada kelompok kandidiasis vaginalis persentase responden dengan diabetes mellitus yaitu $51,7 \%$ lebih tinggi dibandingkan tidak menderita kandidiasis vaginalis yaitu $6,9 \%$. Hasil uji statistik didapatkan nilai $\mathrm{p}=0,001$ ( $\mathrm{p}$ value $<$
0,05) maka dapat disimpulkan terdapat hubungan antara diabetes mellitus dengan kejadian kandidiasis vaginalis.

Perbedaan Kadar Hormon Estrogen pada Kejadian Kandidiasis Vaginalis

Tabel 5. Perbedaan Kadar Hormon Estrogen pada Kejadian Kandidiasis Vaginalis

\begin{tabular}{lccc}
\hline Variabel & \multicolumn{3}{c}{ Kelompok } \\
& $\begin{array}{c}\text { Kandidiasis Vaginalis } \\
\text { (Mean) }\end{array}$ & $\begin{array}{c}\text { Tidak Kandidiasis Vaginalis } \\
\text { (Mean) }\end{array}$ & p value \\
\hline Kadar Hormon Estrogen $(\mathrm{pg} / \mathrm{ml})$ & 143,39 & 60,99 & 0,009 \\
\hline
\end{tabular}

Tabel 5 diketahui bahwa rerata kadar hormon estrogen pada kelompok kandidiasis vaginalis yaitu $143,39 \mathrm{pg} / \mathrm{ml}$ lebih tinggi dibandingkan kelompok tidak menderita kandidiasis vaginalis $60,99 \mathrm{pg} / \mathrm{ml}$. Hasil uji statistik independent $T$ test didapatkan nilai $\mathrm{p}=0,009 \quad(\mathrm{p}$ value $<0,05)$ maka dapat disimpulkan terdapat perbedaan kadar hormon estrogen pada kejadian kandidiasis vaginalis. 


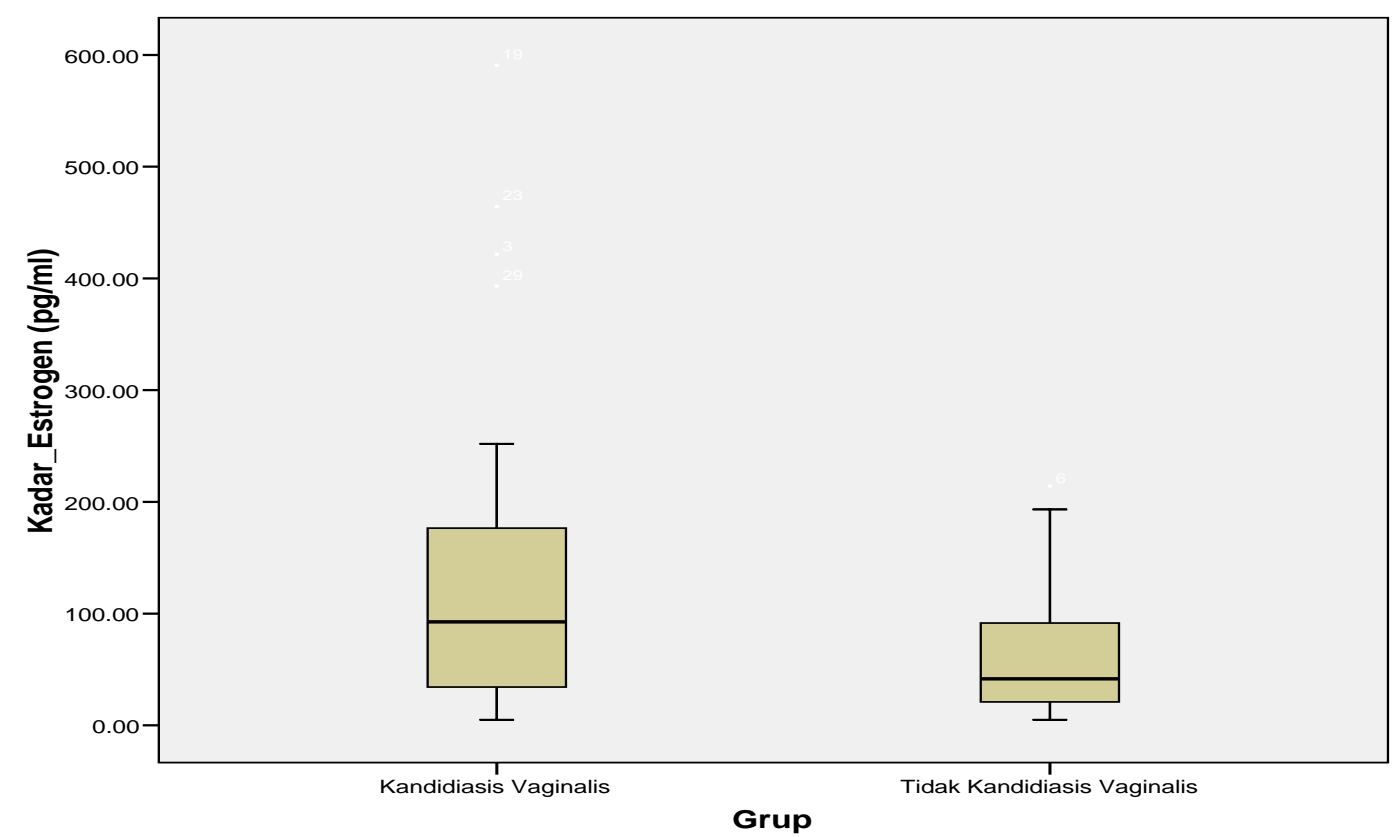

Gambar 2. Perbedaan Kadar Hormon Estrogen pada Kejadian Kandidiasis Vaginalis

Berdasarkan gambar 2 diketahui kadar hormon estrogen lebih tinggi pada responden yang mengalami kandidiasis vaginalis dibandingkan yang tidak mengalami kandidiasis vaginalis.

\section{Multivariat}

Tabel 6. Hasil Seleksi Bivariat Variabel Faktor-Faktor yang Berhubungan dengan Kejadian Kandidiasis Vaginalis

\begin{tabular}{|c|c|c|}
\hline No & Variabel & Pvalue \\
\hline 1 & Higienitas Vagina & 0,000 \\
\hline 2 & Kadar Gula Darah & 0,001 \\
\hline 3 & Kadar Hormon Estrogen & 0,009 \\
\hline
\end{tabular}

Hasil seleksi bivariat diketahui bahwa variabel higienitas vagina, kadar gula dara dan kadar hormon estrogen menghasilkan $\mathrm{p}$ value <
0,25 dan dapat dilanjutkan dengan dilakukan analisis multivariat (Tabel 6).

\section{Tabel 7. Hasil Analisis Multivariat Faktor-Faktor yang Berhubungan} dengan Kejadian Kandidiasis Vaginalis

\begin{tabular}{rcccc}
\hline Variabel & B & Exp (B) & p value & 95\% CI \\
\hline Higienitas Vagina & 2,432 & 11,37 & 0,001 & $2,65-49,32$ \\
Kadar Gula Darah & 2,779 & 16,10 & 0,004 & $2,47-104,63$ \\
Estrogen & 0,001 & 1,001 & 0,578 & $0,99-1,01$ \\
Constant & $\mathbf{- 9 , 2 0 4}$ & & & \\
\hline
\end{tabular}

Tabel 7 analisis multivariat dapat disimpulkan bahwa dari seluruh variabel yang diteliti, yang menjadi faktor dominan dengan kejadian kandidiasis vaginalis adalah higienitas vagina dengan nilai OR 11,37 artinya wanita dengan higienitas vagina yang tidak baik memiliki peluang 11,37 kali untuk mengalami kandidiasis vaginalis dibandingkan yang memiliki higienitas vagina baik.
PEMBAHASAN

Hubungan Antara Higienitas Vagina dengan Kejadian Kandidiasis Vaginalis

Gama (2006) menunjukkan bahwa responden yang melakukan perilaku higienitas vagina yang buruk mempunyai besar risiko 7 kali terkena kandidiasis dibandingkan perilaku higienis vagina yang baik $(\mathrm{OR}=7,2 ; 95 \% \mathrm{CI}=$ 1,2 - 42,5). Penelitian Nsofor (2016) menyatakan bahwa personal hygiene vagina 
berhubungan dengan kejadian kandidiasis vaginalis ( $\mathrm{p}$ value $<0,05$ ), pada penelitian ini mengungkapkan prevalensi kolonisasi kandida vagina berhubungan dengan faktor predisposisi seperti penggunaan celana dalam yang ketat.

Kebersihan vagina dan kelembaban pada vagina yang tidak terjaga dapat menyebabkan banyak keringat terutama pada lipatan-lipatan kulit seperti daerah kemaluan sehingga menyebabkan kulit maserasi. Kondisi ini mempermudah invasi dan kolonisasi Candida albicans (Siregar, 2005; Siregar, 2012).

Berdasarkan observasi peneliti diketahui responden pada penelitian menggunakan antiseptik dalam membersihkan vagina pada kondisi yakni setelah Buang Air Besar (BAB) dan berhubungan seksual. Penggunaan antiseptik dilakukan dengan rutin dalam membersihkan vagina. Jenis antiseptik yang paling sering digunakan oleh responden adalah sabun sirih dan berbagai jenis sabun mandi. Sebenarnya vagina memiliki kemampuan untuk mempertahankan ekosistem/flora-nya cukup dengan membersihkan vagina dengan menggunakan air bersih.

Berdasarkan analisis peneliti terdapat hubungan higienitas vagina dengan terjadinya kandidiasis vaginalis. Hal ini terjadi karena kebersihan vagina dan kelembaban pada vagina yang tidak terjaga dapat menyebabkan banyak keringat terutama pada lipatan-lipatan kulit seperti daerah kemaluan sehingga menyebabkan kulit maserasi. Kondisi ini mempermudah invasi dan kolonisasi Candida albicans, selain daripada itu higienitas vagina yang tidak baik akan meningkatkan risiko perkembangan flora intermediate vagina dan vaginosis bakterial pada wanita yang sebelumnya memiliki flora vagina yang normal. Oleh karena itu perlu adanya perawatan organ genetalia yang baik berdasarkan rekomendasi yang telah ditetapkan.

\section{Hubungan Antara Kadar Gula Darah dengan Kejadian Kandidiasis Vaginalis}

Hasil penelitian sebelumnya Gama (2006) mendukung hasil penelitian ini dengan menunjukkan bahwa penyakit diabetes berhubungan signifikan dengan kandidiasis vaginalis, $\quad \mathrm{OR}=3,53 \quad$ (95\%: 1,268-14,358). Wahyuni (2007) menyatakan persentase kejadian diabetes mellitus pada wanita usia subur pada usia reproduksi (15-49 tahun) adalah 3,6\%. Penelitian Amelia (2009) diketahui terdapat hubungan yang bermakna antara kadar gula darah dengan kejadian kandidiasis vagina ( $\mathrm{p}$ value $<0,05$ ).

Gunther (2014) menyatakan terdapat hubungan diabetes mellitus tipe 2 dengan terjadinya kandidiasis vaginalis ( $\mathrm{p}$ value $<0,05$ ). Mohammadi (2016) menyatakan frekuensi Candida spp. lebih tinggi pada pasien diabetes dibandingkan dengan non-diabetes. Candida spp yang paling sering. pada pasien diabetes adalah Candida albicans $(36.2 \%)$, C. Krusei (10.4\%), C. Glabrata (5.1\%), dan C. tropcalis. (3.4\%).

Berdasarkan analisis peneliti terdapatnya hubungan DM dengan kejadian kandidiasis vaginalisis terjadi karena pada penderita DM terjadi gangguan metabolisme karbohidrat dan perubahan proses glikogenolisis yang menyebabkan kadar glikogen pada epitel vagina meningkat, sehingga pertumbuhan Candida juga akan meningkat. Oleh karena itu perlu adanya upaya bagi penderita DM melakukan pengontrolan gula darah dengan menjaga asupan nutrisi dan pola hidup yang sehat agar mengurangi risiko peningkatan kadar gula darah untuk mencegah terjadinya kandidiasis vaginalis.

\section{Perbedaan Kadar Hormon Estrogen pada Kejadian Kandidiasis Vaginalis}

Barousse (2001) menyatakan peningkatan kadar hormon estrogen dapat meningkatkan risiko kandidiasis vaginalis. Penelitian Wagner (2012) menyatakan kadar hormon estrogen lebih tinggi pada wanita dengan kandidiasis vaginalis yaitu $120,15 \mathrm{pg} / \mathrm{m}$ dibandingkan yang tidak mengalami kandidiasis vaginalis $90,5 \mathrm{pg} / \mathrm{ml}$.

Kadar hormon estrogen berkaitan dengan kejadian kandidiasis disebabkan karena estrogen berperan dalam menentukan kadar zat gula sebagai simpanan energi dalam darah (glikogen). Glikogen merupakan nutrisi dari Lactobacillus yang akan dimetabolisme untuk pertumbuhannya. Sisa dari metabolisme ini melalui suatu enzim, berupa berbagai persenyawaan hidrat arang yang lebih rendah, akan diuraikan lebih lanjut menjadi asetaldehid, asam piruvat, dan akhirnya asam laktat. Asam laktat ini yang menentukan suasana asam di dalam vagina. Peningkatan kadar hormon estrogen berkaitan dengan riwayat pemakaian kontrasepsi hormonal, menyebabkan terjadinya peningkatan hormon pertumbuhan (growth hormone), di mana hormon ini menstimulasi glukosa yang masuk ke dalam sel dengan cepat dipolimerisasi jadi glikogen sehingga endapan glikogen dalam sel meningkat. Oleh karena tingginya kadar glikogen, sehingga tidak semua 
glikogen dimetabolisme oleh Lactobacillus dan ada sebagian glikogen disimpan di permukaan epitel vagina. Hal ini menyebabkan asam laktat yang terbentuk tidak cukup untuk membuat suasana keasaman vagina menjadi normal (Syarif, 2008).

Berdasarkan analisis peneliti terdapatnya perbedaan kadar hormon estrogen antara kandidiasis vaginalis dan tidak disebabkan karena metabolisme estrogen akan menyebabkan tingginya kadar glikogen, sehingga tidak semua glikogen dimetabolisme oleh Lactobacillus dan ada sebagian glikogen disimpan di permukaan epitel vagina. Hal ini menyebabkan asam laktat yang terbentuk tidak cukup untuk membuat suasana keasaman vagina menjadi normal, kondisi inilah yang menyebabkan terjadinya peningkatan kejadian kandidiasis vaginalis. Oleh karena itu perlu dilakukan upaya untuk mencegah peningkatan kadar hormon estrogen yang dapat dilakukan dengan tidak menggunakan kontrasepsi hormonal seperti pil dan menggantinya dengan kontrasepsi jangka panjang. Selain daripada itu menghindari penggunaan terapi sulih hormon.

\section{Faktor Dominan Kejadian Kandidiasis Vaginalis}

Faktor dominan kejadian kandidiasis vaginalis adalah faktor dominan dengan kejadian kandidiasis vaginalis adalah higienitas vagina dengan nilai OR 11,37 artinya wanita dengan higienitas vagina yang tidak baik memiliki peluang 11,37 kali untuk mengalami kandidiasis vaginalis dibandingkan yang memiliki higienitas vagina baik.

Penelitian Gama (2006) menunjukkan bahwa responden yang melakukan perilaku higienitas vagina yang buruk mempunyai besar risiko 7 kali terkena kandidiasis dibandingkan perilaku higienis vagina yang baik $(\mathrm{OR}=7,2$; $95 \% \mathrm{CI}=1,2-42,5)$. Wagner (2012) menyatakan higienitas vagina menjadi faktor dominan dengan terjadinya kandidiasis vaginalis dengan OR 4,5.

Berdasarkan analisis peneliti kebiasaan mencuci tangan yang dianjurkan dalam upaya menjaga higienitas vagina adalah sebelum dan setelah ke toilet serta saat melakukan penggantian pembalut, sedangkan rata-rata pembalut yang harus ditukar pada saat menstruasi dalam sehari adalah 4-5 kali sehari, berdasarkan fenomena dilapangan rata-rata pembalut yang ditukar dalam sehari adalah 1-2 kali sehari, hal ini menggambarkan masih berada dibawah dari rekomendasi yang ditentukan. Selain daripada itu penggunaan antiseptik tidak dianjurkan dalam membersihkan vagina, karena vagina memiliki kemampuan untuk mempertahankan ekosistem/floranya cukup dengan membersihkan vagina dengan menggunakan air bersih.

\section{Keterbatasan Penelitian}

Keterbatasan dalam penelitian ini pertama adalah penilaian untuk mengetahui diabetes melitus yang dilakukan peneliti melalui pengukuran gula darah sewaktu, jika dibandingkan pemeriksaan kadar gula darah puasa lebih baik dibandingkan dengan pemeriksaan kadar gula darah sewaktu. Sebab dengan melakukan pemeriksaan kadar gula darah puasa maka faktor-faktor lain yang dapat meningkatkan kadar gula darah dapat diminimalisir atau bahkan disingkirkan. Sehingga penelitian dapat lebih akurat mengetahui apakah benar bahwa terdapat hubungan yang erat antara kandidiasis vagina dengan kadar gula darah.

Kedua, peneliti tidak melakukan pengukuran kadar hormon estrogen sebelum terjadinya kandiasis vaginalis, sehingga pengaruh peningkatan kadar hormon estrogen terhadap terjadinya kandidiasis vaginalis belum dapat dijelaskan.

\section{SIMPULAN}

Kesimpulan penelitian ini adalah terdapat hubungan higienitas vagina, kadar gula darah dan kadar hormon estrogen dengan kejadian kandidiasis vaginalis.

\section{DAFTAR PUSTAKA}

Ramali L.M., Werdani S. 2001. Kandidiasis Kutan dan Mukokutan. Dalam: Dermatomikosis Superficialis. Perhimpunan Dokter Spesialis Kulit dan Kelamin Indonesia. Jakarta: Balai Penerbit Fakultas Kedokteran Universitas Indonesia

Marschalek, J., et al. 2016. Risk of Vaginal Infections at Early Gestation in Patients with Diabetic Conditions During Pregnancy: A Retrospective Cohort Study. PLOS ONE | DOI:10.1371/journal.pone.0155182 May $11,2016$.

Siregar R.S. 2005. Kandidiasis Penyakit Jamur dan Kulit. Jakarta : EGC. 
2012. Atlas Berwarna Saripati

Penyakit Kulit. Jakarta: EGC.

Anindita, W., Santi, M. Faktor Risiko Kejadian Kandidiasis Vaginalis pada Akseptor KB. The Indonesian Journal of Public Health, Vol 3. No 1, Juli 2006:24-28.

Gama, T. 2006. Beberapa Faktor yang Mempengaruhi Kejadian Kandidiasi Vaginalis. Jakarta : Salemba Medika.

Wahyuni, S., Alkahf, RN. 2007. Diabetes Mellitus pada Perempuan Usia Reproduksi di Indonesia Tahun 2007. Jurnal Kesehatan Reproduksi Vol 3 No. 1, April 46-51.

Amelia, SP. 2009. Hubungan Kadar Gula Darah dengan Kandidiasis Vagina pada Akseptor Kontrasepsi Hormonal. Surakarta : Fakultas Kedokteran Universitas Sebelas Maret.

Afrianty, R., Rangkuti, IF., Kaban, YB. 2016. Hubungan Kadar Estrogen pada Wanita Hamil dengan Kandidiasis Vulvovaginalis. Program Pasca Sarjana. Medan Universitas Sumatera Utara.

Gunther LSA, Martins HPR, Gimenes F, de Abreu ALP, Consolaro MEL, Svidzinski TIE. 2014. Prevalence of Candida albicans and non-albicans isolates from vaginal secretions: comparative evaluation of colonization, vaginal candidiasis and recurrent vaginal candidiasis in diabetic and non-diabetic women. Sao Paulo Med J. 132(2): 116-20.

Barousse MM, Steele C, Dunlap K, Espinosa T, Boikov D, Sobel JD, et al. 2001. Growth Inhibition of Candida albicans by Human Vaginal Epithelial Cells. The Journal of Infectious Diseases. 184: 1489-93.

Wagner RD, Johnson SJ. 2012. Probiotic lactobacillus and estrogen effects on vaginal epithelial gene expression responses to Candida albicans. $\underline{\mathrm{J} \text { Biomed }}$ Sci. 20;19:58.

Syarif, A dkk. 2008. Farmakologi dan Terapi.Ed.5. Jakarta. Bagian Farmakologi FK UI, pp: 451-455 